\title{
Mutual Cooperation Based Go Green: New Concept of Defense Country
}

\author{
Jagad Aditya Dewantara* and Dasim Budimasyah \\ Civic Education Department \\ Universitas Pendidikan Indonesia \\ Bandung, Indonesia \\ *Jagad02@student.upi.edu
}

\begin{abstract}
Growing awareness of state defending in the field of environment is still a challenge for the Indonesian nation. The nation of Indonesia is currently experiencing a deficit of social capital and low implementation of community civilization values. This study aims to analyze and prove that the practice of mutual cooperation go green based community in Glintung village as the initial pioneer of the formation of state defending by promoting the development of village in protecting the environment sector. This qualitative research uses a grounded theory approach. Data were collected by observation techniques, interviews and documentation studies. The results showed that mutual cooperation based on go green in Glintung village which has a state defending contents resulted in the development of green infrastructure, water saving infrastructure, waste management infrastructure and the emergence of urban farming movement. The practical implications of mutual cooperation based on go green succeeded in building a sense of nationality of citizenship through the active participation of the community in every work activity of the village development, besides that mutual cooperation based go green can foster the responsibility of society as citizens who uphold the value of nationalism.
\end{abstract}

Keywords - defense country; mutual cooperation; go green

\section{INTRODUCTION}

The low sense of the state defenses, the low solidarity and trust among members and community groups in Indonesia is caused by social capital deficits (social capital) and low implementation of community civilization (civility) [1]. Every year Indonesia loses 684,000 hectares of forest due to illegal logging, forest fires, and forest conversion. In 2016 there are as many as 65 cases of illegal logging and in 2017 that number decreased to 16 cases of illegal logging (Kompas, 2017).

The problem of environmental cleanliness and environmental pollution are also a concern for Indonesia today, the level of air pollution in Indonesia is currently very worrying. The level of air pollution in Indonesia is ranked eighth after seven other countries namely China, India, Pakistan, Bangladesh, Nigeria, Russia, and the United States (Detiknews, 2015). For citizens of Indonesia, efforts to defend citizens are based on the love of the homeland (archipelago) and the awareness of the nation and state of Indonesia with the belief in Pancasila as the basis of the state and based on the UUD 1945 as state constitution [2].
Amanda Alexander's research (2016) is manifested by conscription and participates in wars to defend the country. Rogers Brubaker's research states that a sense of patriotism and nationalism can be realized by maintaining civic engagement [3]. Yurong $\mathrm{He}$ and Andrea Wiggins research states that awareness in the field of environment can be realized with the application of civics science [4].

In contrast to previous research that manifested the defense of the state only by taking up arms and only through education, then the efforts made to overcome the problem of lack of awareness of the state defend the gotong royong movement based on go green in Glintung Malang village. Glintung village with densely populated population, low level of education, and the heterogeneity of the community profession require a lot of art and science in managing and maintaining the sustainable conservation of Glintung village. Chairman of RW Glintung village appoints several captains of hallway who are fully responsible for the implementation and sustainability of green infrastructure in the region, and overcome the problem in case of environmental damage.

The mutual cooperation based on go green in Glintung village is a movement to safeguard, maintain and build environmentally based village conditions and can also be interpreted as an effort to promote green environment and hygiene in kampung environment, one of the activities is the activity of greening the village. The research on mutual cooperation based on go green aims to maintain the glorious values of Glintung village culture and improve the environment condition of facilities and infrastructure while still absorbing modern values to enrich the socio economic aspect of society.

\section{A. The Concept of Mutual Cooperation Theory}

Mutual cooperation has the meaning of working together to achieve the same goal. Mutual cooperation has a very close ties with Pancasila, even gotong royong is a source of Pancasila's soul that is anxious to the Indonesian people ever since, now and in the future. The future of the nation and the achievement of a fair and prosperous society requires the willingness of citizens to reestablish the spirit of mutual support, and to bring harmony and tolerance from leaders, both state and regional leaders, political and economic leaders, 
as well as religious and group leaders [5]. Mutual cooperation is a custom of help to help people in various fields of social activity, either based on the efficient, practical based on kinship relationships and other collaborative activities [6].

Mutual cooperation is an ongoing tradition that is constructed both by the state and local people, it is done to become a final process that can influence the dominant political and cultural system of Indonesia [7]. From some explanations about mutual cooperation, it can be concluded that what is meant by mutual cooperation is a customs. Mutual cooperation is also a civic virtue of the Indonesian nation. Gathering activities in various dimensions provide implications or benefits to human resource development and to improve the welfare of the community through the value of togetherness in doing the difficult work to be done alone, and used as an effort to improve the awareness of state defense in Indonesia [8]. Mutual cooperation involves communities and communities, so what these communities and communities do will show how well civic virtue communities and communities are doing. The most central and necessary civic virtue to be developed is the willingness of citizens to place public interests above personal interests [9].

\section{B. Civic Virtue}

Civic virtue is an individual psychosocial domain that substantively has two elements, namely civic disposition and civic commitments [10]. Civic Virtue is "... the willingness of citizen to set aside private interests and personal concerns for the sake of the common good". That is the willingness of citizens to place public interests above personal interests [11]. Civic virtue (civic civilization) can also be interpreted as “... as the set of skills, dispositions, and traits of character conducive to democratic self-government and that a proper component of a formative project is to foster democratic selfgovernment.." or a set of skills, characters, and character traits that produce a democratic person in which the main component relates to the development of a democratic citizen [12].

The domain of civic virtue has three different views: a) civic virtue is different from individual values; b) the value of being a good person is surpassed by the value needed to be a good citizen, so that learning about governance is needed to build a democratic government; c) the value of being a good citizen is exceeded by the value needed as a good person, so everyone should evaluate his personality and commit himself as a civilized citizen [12].

\section{The Concept of State Defense Theory}

The state defense is an organized, comprehensive, integrated and continuing citizen's determination, attitude and action based on the love of the country and the realization of national and state life with the belief in Pancasila as the basis of the state and resting on the 1945 Constitution as the state constitution [2]. State defense is the right and duty for all Indonesian citizens as stated in clause 27 paragraph 3 and clause 30 of the 1945 Constitution.

Nationalism is a belief or doctrine for the love of the nation and state of the consciousness of membership or citizens who potentially jointly achieve, defend, and devote the identity, integrity, prosperity and power of the nation. Nationalism generally involves the identification of ethnic and state identity. Nationalism is a cultural phenomenon rather than a political phenomenon because nationalism is rooted in prominent ethnicity and culture [13].

The existence of nationalism, the people can believe that the nation is very important. Nationalism is also a word that is understood as a movement to establish or protect the homeland [14]. Nationalism is an ideology that puts the nation at the center of its problems and seeks to heighten its existence [15]. Nationalism, in particular, remains the preeminent rhetoric for attempts to demarcate political communities, claim rights of self-determination and legitimate rule by reference to the people of a country [16].

\section{Go Green}

Go green is an activity that needs to be done conceptually in handling environmental crises. In a broad sense go green is all effort to restore, maintain and improve the condition of land in order to produce and function optimally, either as water regulator or environmental protection [17]. Nazarudin (1994) in Pramono [18], states go green is the effort of environmental arrangement by using the plant as its main material, so that from the plant can be taken many benefits.

Go green can make biotic environment with various functions in environmental order. These functions can be directly related to the life of the people living in the environment as a single ecosystem. Go green aims to create a residential area that is environmentally sound. The atmosphere is beautiful, harmonious and cool trying to be displayed again like residential houses, public facilities, watersheds, highways and elsewhere planted with various trees and plants [18].

\section{METHOD}

This research used a qualitative paradigm with grounded theory research design that emphasizes the discovery of theory from empirical observation data in field with inductive method (finding theory from some data), generative that is invention or construct theory using data as evidence, constructive finding theory or category construction through analysis and the process of abstracting, and subjectively that is reconstructing the interpretation and interpretation of research results based on the conceptualization of society subjected to study [19]. The research is located in Glintung village. During the first study conducted was observation, followed by interviews, and documentation with informants. The results of data collection obtained are then analyzed using Miles and Huberman models. The data obtained is then validated using triangulation technique.

\section{RESULT AND DISCUSSION}

The results obtained from the research in Glintung village showed that gotong royong based go green conducted in Glintung village can be used as a model of state defense, because the state does not have to take weapons but to promote the country and build the country one of them with go green-based mutual cooperation. This is evidenced by the 
results of observation data, interviews and documentation in the village Glintung.

Glintung village is a densely populated village that belongs to four RT and is inhabited by 320 families with a total population of 1,154 people, has now become a pioneer of the Water Saving Movement (GEMAR) until the famous Glintung Go Green Village (3G). At the beginning of the village development Glintung go green chairman of RW admitted getting difficult to move the citizens, residents in RW 23 only want to move if get wages. So to overcome the problem the chairman of RW 23 has its own strategy to be able to move its citizens, although it is not uncommon to get scorn and allegations of his citizens. The strategy that is done by the chairman of RW 23 is to ask every citizen who wants to ask for stamp should plant the plants in front of their house and can use the planting media in the form of used tins, bottles, etc., so will not burden the villagers to buy media planting which is expensive. With the strategy used by the chairman of RW 23, the villagers who previously disagreeing at this time mutually cooperate to realize the village is more green and more beautiful.

The concept of the practice of mutual cooperation based on go green in Glintung village as a model of state defense is obtained that in Glintung village there are Dalu community work activity that is work devotion done at any time by their own initiative in their home environment to keep environment, held every Saturday, coaching activities to other villages visiting the village of Glintung and the existence of urban farming activities. The purpose of the mutual cooperation based on go green practice created beautiful and care for Glintung village, improve the facilities and infrastructure of Glintung village, and grow awareness of the environment. On the number and level of participation of Glintung village people and community background it is found that all Glintung village residents from RT I - RT IV participate and community background of Glintung village majority work as laborers, small businessmen and private employees. Country defend model which is derived from the practice of mutual cooperation based on go green that is the work of caring for the village, aware of the cleanliness of the village, maintaining the security of the village together, the attitude of tolerance and help to help the villagers, and not to waste in any place.

Mutual cooperation based on go green provides lesson that how important the formation of self-starting from hard work and mutual cooperation, to form strong character inside by giving stimulus response to be able to form its own character. This is in line with the research entitled Batak Toba Society's local wisdom of mutual cooperation in the Toba Lake area: a linguistic anthropology study which showed that mutual cooperation in Batak Toba society has the basic rules of togetherness, hard work, and sustainable practice in life, work as well as joint activities [8]. Mutual cooperation has a very close bond with Pancasila, and even mutual cooperation is the radiance of Pancasila soul. The future of the nation and the achievement of a just and prosperous society need the citizens' willingness to regenerate the attitude of the mutual help culture, while creating harmony and tolerance that starts from leaders, both state and local leaders, political and economic leaders and religious leaders and groups [5].

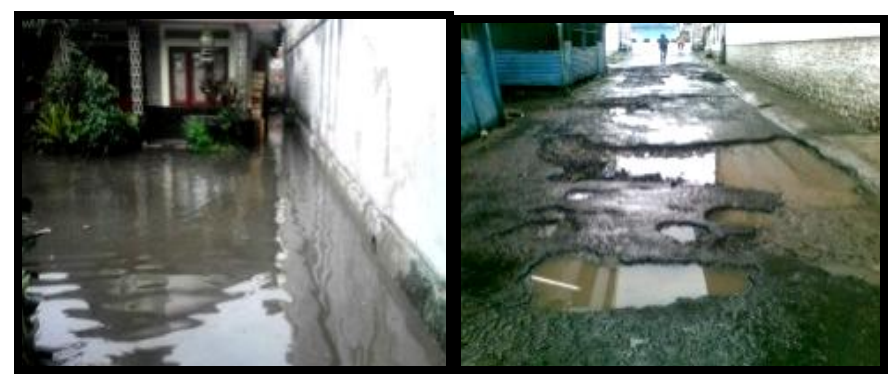

Fig. 1. The condition of glintung village before mutual cooperation based on go green activities

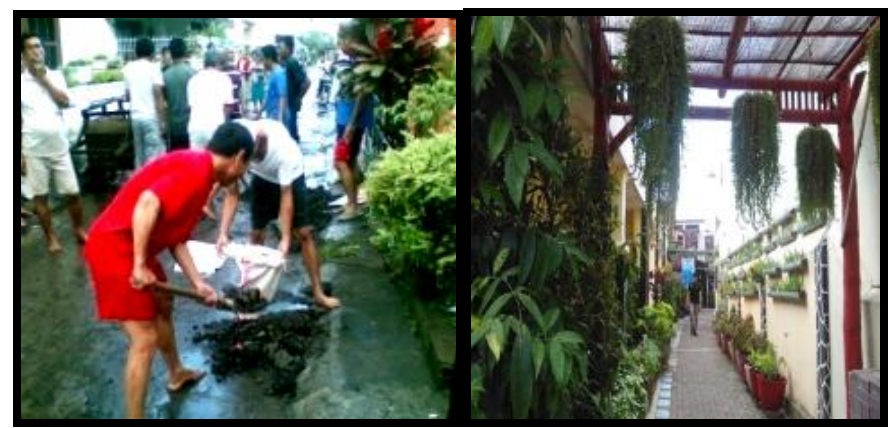

Fig. 2. The situation of glintung village after the mutual cooperation based on go green activities

Developing a green environment is an effort that requires harmony between the environment and all its aspects. The objectives of the development of green infrastructure in $3 \mathrm{G}$ village include: (1) launching the potential of $3 \mathrm{G}$ village as an environmentally sound development site through reforestation, water saving movement and waste management; (2) to be a review of various government policies, to be the goal of community service programs from universities and become the objectives of CSR from the private sector in the effort to realize the area of village $3 \mathrm{G}$ as an environmentally sound area; (3) a solution that is in line with the expectations of the citizens of village $3 \mathrm{G}$ on all the environmental issues that have been faced.

TABLE I. Mutual COOPERATION RESUlts Go GREen BASED ON STATE DEFENSE

\begin{tabular}{|c|c|c|}
\hline $\begin{array}{c}\text { Mutual } \\
\text { Cooperation } \\
\text { Results Go } \\
\text { Green }\end{array}$ & \multicolumn{1}{|c|}{ Description } \\
\hline $\begin{array}{l}\text { Infrastru } \\
\text { cture dev } \\
\text { elopment }\end{array}$ & $\begin{array}{l}\text { The development of green infrastructure (green } \\
\text { infrastructure) is a development that requires various } \\
\text { innovations for sustainable reforestation process and can } \\
\text { provide benefits, both socially and economically for the } \\
\text { community. The concept of green infrastructure } \\
\text { development in Glintung village in a way: } \\
\text { - Vertical Garden: the concept of vertical garden was } \\
\text { chosen because the village of 3G did not have } \\
\text { sufficient green open space, so the pattern of planting } \\
\text { the people in the halls of the village using bamboo } \\
\text { media and recycling of garbage (plastic bottles used } \\
\text { beverages, etc.) that were glued/ taped to the wall and } \\
\text { planted with various plants, especially where it is } \\
\text { possible to receive sunlight. }\end{array}$ \\
\hline
\end{tabular}




\begin{tabular}{|c|c|c|}
\hline & & $\begin{array}{l}\text { - Horizontal Garden: around the house residents are } \\
\text { required to have green plants with good pot media } \\
\text { from used bottles, used pan, and polybags. } \\
\text { - Sky Garden: maximize the space above the roof of the } \\
\text { house for residents to plant land. } \\
\text { - Flying Garden: planting with a pattern hanging over } \\
\text { empty alley aisle, material from tompo (place of rice } \\
\text { from bamboo) and inside it filled with polybag. } \\
\text { - Mobile Garden: planting with hydroponic media that } \\
\text { can be moved and placed as needed. }\end{array}$ \\
\hline & $\begin{array}{l}\text { Infrastru } \\
\text { cture } \\
\text { Develop } \\
\text { ment } \\
\text { Saving } \\
\text { Water }\end{array}$ & $\begin{array}{l}\text { The water saving movement in principle is to include an } \\
\text { abundance of rainwater as much as possible into the soil. } \\
\text { The movement of saving water can be done through } \\
\text { several ways by the citizens that is by making: } \\
\text { - Injection wells with a diameter of } 1 \text { meter and a depth } \\
\text { of } 5 \text { meters that can hold water } 6000 \text { liters; } \\
\text { - Biopori small use } 4 \text { inch paralon pipe with a depth of } \\
1 \text { meter that can hold } 10 \text { liters of water; } \\
\text { - Biopori jumbo using a can of } 25 \text { kilogram wall paint } \\
\text { with a depth of } 1 \text { meter that can hold } 20 \text { liters of } \\
\text { water; } \\
\text { - Biopori super jumbo using a can of } 25 \text { kilogram wall } \\
\text { paint with a depth of } 1 \text { meter that can hold } 50 \text { liters of } \\
\text { water; } \\
\text { - The absorption trenches } 80 \text { centimeters wide, } 1 \text { meter } \\
\text { deep and } 20 \text { meters long are expected to hold water } \\
\text { equivalent to } 300 \text { biopores or equivalent to } 3,000 \\
\text { liters of water. }\end{array}$ \\
\hline & $\begin{array}{l}\text { Construc } \\
\text { tion of } \\
\text { Waste } \\
\text { Manage } \\
\text { ment } \\
\text { Infrastru } \\
\text { cture }\end{array}$ & $\begin{array}{l}\text { The waste management infrastructure in } 3 \mathrm{G} \text { village is } \\
\text { implemented through the following ways: } \\
\text { - Sorting out the wet and dry trash from the residents' } \\
\text { house; } \\
\text { - Put the selected garbage into the shared garbage that } \\
\text { is in certain places; } \\
\text { - Incorporating wet garbage (organic) that can be used } \\
\text { as compost into the hole biopori; } \\
\text { - The inorganic wet garbage taken by the garbage } \\
\text { officer is then taken to a temporary garbage dump. }\end{array}$ \\
\hline & $\begin{array}{l}\text { The } \\
\text { emergen } \\
\text { ce of the } \\
\text { Urban } \\
\text { Farming } \\
\text { Moveme } \\
\text { nt }\end{array}$ & $\begin{array}{l}\text { Urban farming is the concept of transferring } \\
\text { conventional agriculture to urban cultivation, the } \\
\text { difference with conventional farming is in the actors and } \\
\text { the planting medium. The urban farming movement of } \\
\text { Glintung Village residents is by planting green } \\
\text { vegetables as a source of healthy nutrition, reducing } \\
\text { vegetable imports, greening the environment and helping } \\
\text { to reduce the impact of global warming. }\end{array}$ \\
\hline
\end{tabular}

Source: Research Observations (2018)

The results of the go green based mutual cooperation can be seen in Table 1. Mutual cooperation based go green with state defensive arena resulted in green infrastructure development, water saving infrastructure development, construction of waste management infrastructure, and the emergence of urban farming movement.

Development of green infrastructure in Glintung village requires a one year educational process that will slowly change the mindset of the citizens to be creative and produce the concept of Glintung Go Green infrastructure that is vertical garden, horizontal garden, sky garden, flying garden and mobile garden. The garden vertical infrastructure is also known as a green wall, vertical garden or bio wall. Vertical garden consists of vertical structures that are plants that may or may not be attached to buildings or interior walls [20]. In the green vertical garden infrastructure system specially designed in developing plants through building walls [21]. The green construction on the vertical garden consists of green roofs, inner and outer walls, monitoring systems, collecting rainwater and wastewater management and reusing it for irrigation [22]. Another system of green infrastructure development that is today became famous and as part of the green city of vertical farm [23]. The vertical farm system was developed and designed to grow crops that can provide for urban food needs [24]. The vertical greening system has been used for many years and now the system is becoming more important as it is needed to increase citizens' awareness of the environment [22]. The development of green infrastructure is an important indicator for the environment [25]. The development of green infrastructure has four benefits for society, namely social, health, environment and economy [26].

The development of green infrastructure provides many benefits to society and can overcome negative effects on the environment [27]. The development of green infrastructure is an important indicator for the environment [25]. The development of green infrastructure has four benefits for society, namely social, health, environment and economy [26]. The development of green infrastructure provides many benefits to society and can overcome negative effects on the environment [27].

The infrastructure development of water saving in Glintung village is done by making injection and biopori wells. The water saving movement program (GEMAR) is selfhelp movement in Glintung village to prevent floods and droughts, with reference to Minister of Environment Regulation No. 12/2009 on Rain water Utilization. Biopori Absorption Hole (LRB) is basically built to restore the soil's function in enhancing water retention. The water saving program brings a positive impact on the local community, with beautiful, clean, flood free, and religious, self-sustaining and innovative human resources.

Waste management that is done close to the source, especially for organic waste is one way of waste management recommended in Law number 18 year 2008. The absorption hole technology with biopori has been known to accelerate water absorption by utilizing organic waste [28]. The drainage system can be applied soil at flood locations as all flood locations have sand content that is capable of absorbing water. The hole is then filled with organic waste and stored in a hole so that it will support the existing microorganisms in the soil capable of creating biopores [29].

The benefit of bipori is improve soil ecosystems, absorb water and prevent floods, increase groundwater reserves, cope with drought, facilitate waste management and maintain cleanliness, convert waste into compost, reduce greenhouse gases and methane emissions, and overcome the problem of inundation [28]. Development of existing settlements in Indonesia is Glintung Malang village more and more land covered by buildings, so that the rain water absorbed into the soil is less, then the community of Glintung village build 1000 biopori that can serve to reduce the flood of puddles and water flow in the soil surface. 
The urban farming movement carried out in Glintung village begins with a unique model that each house is required to have green plants as a condition for obtaining population administration services. For those who can not afford to buy crops, the RW provides plants and is obliged to take care of them. Urban farming contributes to the improvement of sustainability in cities by improving the quality of the building environment [30]. Urban farming can also reduce the negative impact of urbanization on the environment by adding green space to the environment and the beauty of the land [31].

Urban farming provides a positive value not only in the fulfillment of food needs but also there are practical values that can affect the ecological and economic sustainability of urban areas. If urban farming practices are done with regard to environmental aspects, it has many advantages. The benefits of urban farming can be seen from economic, ecological, social, aesthetic, educational, and tourism aspects [32]. Another benefit of urban farming is creating access to the often limited land in urban areas by creating green spaces within the city to ensure people to grow vegetables [33].

Another social impact of urban farming is providing a medium for learning experiences of preserving the environment, educational programs, and development for youth [34]. The existence of urban farming in Kampung Glintung can be used as a means to optimize the utilization of land and natural resources by using appropriate technology. People who are generally busy because of work, urban farming can be a medium to take advantage of free time. Optimizing land use and utilizing spare time for activities in urban farming will bring them closer to access to food and maintain environmental sustainability in the presence of green open space [35].

Development of waste management infrastructure in Glintung village is realized with the management of Dewandaru's garbage bank which is a very important part of 3G movement. Dewandaru garbage bank management in accordance with go green theories are reduce, recycle, refuse and replace. The management of Dewandaru's garbage bank managed by the villagers of Glintung it self who work together to manage waste into more useful items. Reduce is an effort made to reduce waste and save the use of goods so as not to cause excessive waste. Recycle is recycling waste or waste that is not useful and turning waste or waste back into useful items or into new products. With the recycling of waste it will save resources and send less waste to landfills that can help in reducing air and water pollution [36]. Reuse is by reusing garbage which can still be utilized. Replace by appealing to residents to minimize plastic bag waste by replacing them with baskets for daily shopping activities and replacing other materials for Styrofoam waste because they can not be degraded naturally [37].

Impact of activity or contribution based mutual assistance activities go green to the country as part of a form of defending the country found that with practice mutual cooperation based on go green will have an impact on some aspects of social, educational, economic, ecological, and protection and management of the environment.

TABLE II. IMPACT MUtUAL COOPERATION BASED ON GO GREEN

\begin{tabular}{|c|c|c|}
\hline Impact & Target & Description \\
\hline 1. Ecology & $\begin{array}{l}\text { - All Villagers } \\
\text { Glintung } \\
\text { - Residents } \\
\text { outside the } \\
\text { village around } \\
\text { glintung }\end{array}$ & $\begin{array}{l}\text { - The movement of saving water } \\
\text { of the village of } 3 \mathrm{G} \text { impacted } \\
\text { the new springs dikampung } \\
\text { around } \\
\text { - Citizens are able to preserve } \\
\text { the environment by } \\
\text { maintaining the noble values } \\
\text { of the nation's culture }\end{array}$ \\
\hline 2. Social & $\begin{array}{l}\text { - All Villagers } \\
\text { Glintung } \\
\text { - Residents } \\
\text { outside the } \\
\text { village around } \\
\text { glintung }\end{array}$ & $\begin{array}{l}\text { - } \text { The mutual cooperation } \\
\text { program raises people's } \\
\text { awareness to help each other } \\
\text { out } \\
\text { - Enhance the sense of } \\
\text { togetherness and sharing in } \\
\text { each activity } \\
\text { - Improving social interaction } \\
\text { among villages }\end{array}$ \\
\hline 3. Economy & $\begin{array}{l}\text { - All villagers } \\
\text { glintung }\end{array}$ & $\begin{array}{l}\text { - Increasing economic } \\
\text { resilience is the formation of } \\
\text { local economy } \\
\text { - Opening opportunities for } \\
\text { people to develop creative } \\
\text { economy }\end{array}$ \\
\hline 4. Education & 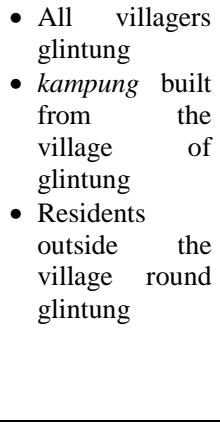 & $\begin{array}{l}\text { - Mutual cooperation go green } \\
\text { becomes an alternative means } \\
\text { of environmental education } \\
\text { - Providing training program } \\
\text { information for the target } \\
\text { villages according to their } \\
\text { priorities and needs } \\
\text { - The socialization of mutual } \\
\text { cooperation based on go green } \\
\text { program can increase the } \\
\text { knowledge and motivation of } \\
\text { the community to care for the } \\
\text { environment }\end{array}$ \\
\hline $\begin{array}{l}\text { Protection } \\
\text { and } \\
\text { manageme } \\
\text { nt of the } \\
\text { environme } \\
\text { nt }\end{array}$ & $\begin{array}{l}\text { - All villagers } \\
\text { glintung } \\
\text { - Indonesian } \\
\text { country }\end{array}$ & $\begin{array}{l}\text { - Assisting Government } \\
\text { Program in accordance with RI } \\
\text { Law No. } 32 \text { of } 2009 \text { on } \\
\text { Greening and Conserving the } \\
\text { Environment }\end{array}$ \\
\hline
\end{tabular}

The impact of education mutual cooperation based on go green is as a means of increasing knowledge and motivation of the community to care for the environment. The economic impact of mutual cooperation based on go green is to increase economic resilience with the formation of the local economy. The social impact of the mutual cooperation based on go green practice is to increase awareness of a sense of togetherness in every activity. The ecological impact of the practice of mutual cooperation based go green is able to change the impression of a more attractive area, green and healthy.

The impact of nationalism of Glintung village people to always maintain and preserve the environment is reflected in the mutual cooperation based go green. People always take time, energy and mind in every activity in Glintung village. Mutual cooperation based on go green in Glintung village raises public awareness to help each other, a sense of 
togetherness and sense of sharing. Maintaining the noble values of the culture as well as absorbing modern values to enrich the socio economic aspect is an impact of integrity generated from mutual cooperation based go green. The impact of the practice of mutual cooperation based go green in the protection and management of the environment is to assist government programs in preserving the environment. The practice of mutual cooperation based go green has a broad impact as a form of defending the state and is expected to trigger the involvement of all citizens in preserving the environment.

The spirit of nationalism and patriotism to love the environment indirectly arose from the hard work of the Glintung people in building the village for the better. Nationalism is belief or doctrine for the love of the nation and the state of the consciousness of membership or citizens who potentially jointly achieve, defend, and devote the identity, integrity, prosperity and strength of its people [13]. With the existence of nationalism in a way to love the environment will make people aware of the hard struggle that has been done and achieved and must be maintained because it is not easy to get it. This is in line with the theory of nationalism which states that "...with the national or patriotic idea so weak and undeveloped, it arguably makes more sense to analyze rival ideas of the nation held by the country's different ethnic groups" which means that the existence of nationalism, the people can believe that the nation is very important. Nationalism is also a word that is understood as a movement to establish or protect the homeland [14].

Mutual cooperation based on go green impact on the mindset of the people that in building the village is not easy, therefore need to maintain the village with a whole heart and sincerity. Forming the soul of nationalism and state of civic virtue is started from coercion and hard work and the existence of guidance to society that continuous in reach something to be embedded strong soul and high sense of belonging, with existence of stimulus hard work that continuously done hence will create a sense of belonging and a sense of satisfaction in society will have a psychological impact on the sense of pride of the results achieved. This is in line with research that nationalism and patriotism can motivate citizens and can help generate a sense of solidarity and responsibility [3]. Patriotism becomes an element of personal identity the most important is the commitment to joint participation in doing the same activities based on the same perception [38].

Mutual cooperation in the Glintung village based on go green is a cooperation program among the citizens to create a clean, healthy, safe and beautiful environment, in the aspect of defending the country mutual cooperation Glintung village is state defending model that can nurture the love of the country. This is in contrast to Machida's research in which the sense of patriotism and nationalism is enhanced by military action, so that the state's defense can be seen from the attitude of citizens against the state that will seize power [39]. The role of youth is urgently needed in the defense of the country and therefore the Japanese government requires all youths to under go compulsory military training and guidance on state defense [40].

State defending efforts in Indonesia is different from the state defending overseas, if overseas defend the country should take up arms. Singapore is the fastest country in the development of military capability that makes Singapore the strongest and best state in military defense compared to other Southeast Asian countries. Singapore's efforts to improve economic development are by improving the military defense system in the form of possession of weaponry and strategies to carry out attacks [41]. State defending efforts in Indonesia can be realized with the practice of mutual cooperation based on go green which is one of the basic description of the core of state defense counseling as stated in the Law No 3 of 2002 clause 9 paragraph (1) on the State Defense and the Constitution 1945 clause 27 paragraph (3) that every citizen shall have the right of duty and shall participate in the defense of the state. It means every citizen have the right to obtain protection from the state and are obliged to participate in the defense of the state, defending the state not necessarily in the form of war. Law No. 20/1982 on Basic Provisions on Defense of the Security of the Republic of Indonesia clause 8 states that the participation of citizens in the defense of the state can be realized in accordance with the capabilities and expertise of each individual in the components of the defense force of state security.

Mutual cooperation based on go green will increase public awareness of the environment and build the nation's character. Building on the character of the nation is a process of giving citizens a more independent position in relation to the state, promoting a democratic ethos that not only emphasizes individual rights and the rule of law, but also utilizes the enhancement of moral relations among citizens, instilling harmony values that awaken the care of all citizens and the fate of all nations [42].

The impact of the activities or contribution of the mutual cooperation based on go green activities to the state as part of the state's defense had an impact on several aspects, from the social aspect of mutual cooperation based on go green, raising public awareness to help each other in facing the problems. Enhance the sense of togetherness and sharing in each activity. Social reciprocity can create a spirit of mutual cooperation between villagers, as in everyday life when the villagers know each other and trust each other. The spirit village program is one of the programs that is in line with the mutual cooperation based on go green program, which emphasizes community awareness to the environment. The spirit village program is based on the experiences of the elders about how to live in a shared environment and keep the harmony of the environment [43].

The ecological impacts generated through the mutual cooperation based on go green activities are the presence of garbage banks in the village of Glintung in line with the concept of greening 4 R (Recycle, Reduce, Replace, Reuse). 
Waste management should be done from micro level at household to macro level in city and country. The benefits of waste management, among others, socio economic and environmental impacts, long-term goals can reduce the environmental impact caused by solid waste, empower communities from low income groups to manage waste into more useful goods, can be used as an effort in recycling [44].

Other ecological impacts of the mutual cooperation based on go green activities are utilizing open space for hydroponic plants and road bodies as green areas, so as to change the impression of the area becomes more attractive, green and healthy and to preserve the water resources through water conservation. This is in line with the study of urban farming explaining that urban farming implemented in urban areas will increase civic virtue in the environmental field and increase community responsibility for ecological integrity in the environment [45].

Mutual cooperation based on go green is one way to stimulate citizens to love the environment and form a disciplined person because the awareness of defending the country is based on efforts, actions and activities are done efficiently and effectively, in order to obtain a better result than before and behavior inspired by the love of the Republic of Indonesia, based on Pancasila and the 1945 Constitution [46].

\section{CONCLUSION}

Mutual cooperation based on go green is the latest find in the concept of defending the country where the state defend not only by taking up arms but by building the environment. This is evidenced from the impact resulting from mutual cooperation based on go green. Mutual cooperation based on go green contributes to the country. All things that contribute to the state are a form of state defense. This research can be developed by further researchers in other scientific fields such as in the field of environment and socioeconomic. The findings in this study can be a new contribution to the science of Citizenship Education aimed at realizing smart and good citizenship.

\section{REFERENCES}

[1] Budimansyah. 2016. Teori Sosial dan Kewarganegaraan. Bandung: Widya Aksara Press.

[2] Winarno. 2013. Pendidikan Kewarganegaraan untuk Pendidikan Tinggi. Jakarta: PT. Bumi Aksara.

[3] Brubaker, Rogers. 2004. In the Name of the Nation: Reflections on Nationalism and Patriotism. Citizenship Studies 8 (2): 115-127.

[4] He, Yurong et al. 2017. Implementing an Environmental Citizen Science Project: Strategies and Concerns from Educators' Perspectives. International Journal Of Environmental \& Science Education 12 (6): 1459-1481.

[5] Suryohadiprojo, Sayidiman. 2016. Budaya Gotong Royong dan Masa Depan Bangsa. Jakarta: Kompas Media Nusantara.

[6] Koentjaraningrat. 2004. Kebudayaan Mentalitas dan Pembangunan. Jakarta: PT. Gramedika Pustaka Utama.

[7] Bowen. 1986. On the Political Construction of Tradition: Gotong Royong in Indonesia. The Journal of Asian Studies 45 (3): 545-561.
[8] Sibarani. 2018. Batak Toba Society's Local Wisdom of Mutual Operation in Toba Lake Area: A Linguistic Antropology study. International Journal of Human Right in Healthcare 11(1) : 40-55.

[9] Chambel et al. 2011. The psychological contract of call-centre workers: Employment conditions, satisfaction and civic virtue behaviours. Economic and Industrial Democracy 32 (1): 115-134.

[10] Winataputra, Udin Saripudin. 2015. Materi Pokok Pendidikan Kewarganegaraan: Refleksi Historis-Epistemologis dan Rekontruksi Untuk Masa Depan. Tangerang Selatan: Universitas Terbuka.

[11] Winataputra, U dan Budimansyah. 2007. Civic Education: Konteks, Landasan, Bahan Ajar, dan Kultur Kelas. Bandung: Program Studi Pendidikan Kewarganegaraan SPs UPI.

[12] Mc.Clain, L. C. 2001. The domain of civic virtue in a good society: families, schools, and sex equality. Fordham Law Review 69 (5): 16171666.

[13] Hutchison. 2000. Ethnicity and Modern Nations. Ethnic and Racial Studies 23 (4): 651-669.

[14] Hyman, A. 2002. Nationalism and the Colonial Legacy in the Middle East and Central Asia. International Journal of Middle East Studies 34 (2): 189-203.

[15] Smith. 2003. Nasionalisme Teori, Ideology, Sejarah. Jakarta: LP3LS.

[16] Calhoun. 1993. Nationalism and Ethnicity. Annual Review of Sociology 19: 211-239.

[17] Ibrahim S, Daut I, Irwan YM, Irwanto M, Gomesh N, Farhana Z. Linear regression model in estimating solar radiation in Perlis. Energy Procedia. 2012 Jan 1;18:1402-12.

[18] Pramono, Susatyo. 2007. Penghijauan Sebagai Salah Satu sarana Mewujudkan Kota Berwawasan Lingkungan. Teodolita 8 (2): 28 - 39.

[19] Emzir. 2012. Metode Penelitian Kualitatif Analisis Data. Jakarta: Rajawali Pers.

[20] Kontoleon and E.A. Eumorfopoulou. 2010. The Effect of the Orientation and Proportion of a Plantcovered Wall Layer on the Thermal Performance of a Building Zone. Building and Environment 45:12871303.

[21] Ottelé M, van Bohemen HD, Fraaij AL. Quantifying the deposition of particulate matter on climber vegetation on living walls. Ecological Engineering. $2010 \mathrm{Feb}$ 1;36(2):154-62.Urrestarazu et al. 2016. Vertical Greening Systems and Sustainable Cities. Journal of Urban Technology: $1-21$.

[22] Abel. 2010. The Vertical Garden City: Towards a New Urban Topology. Council on Tall Buildings and Urban Habitat Journal 2: 20-30.

[23] Despommier. 2011. The Vertical Farm: Controlled Environment Agriculture Carried Out in Tall Buildings Would Create Greater Food Safety and Security for Large Urban Populations. Journal für Verbraucherschutzund Lebensmittelsicherheit 6 (2): 233-236.

[24] Mell, I. C. 2008. Green Infrastructure: Concepts and Planning. Forum Ejournal : 69-80.

[25] Mansor, M. Said, I. and Mohamad, I. 2012. Experiential Contacts with Green Infrastructure's Diversity and Well-being of Urban Community. Procedia - Social and Behavioral Sciences 49 : 257 - 267.

[26] Nazir et al. 2014. Green Infrastructure and its Roles in Enhancing Quality of Life. Procedia - Social and Behavioral Sciences 153 ( 2014 ) $384-394$.

[27] Hutapea et al. 2018. Waste Management with the Technology of Biopore Hole Absorption (LRB) Based on Biocharin Medan, Indonesia. Journal of Environmental Science, Toxicology and Food Technology 12 (3): 11-14.

[28] Daud et al. 2014. Experimental Study of The Diameter and Depth Pore Hole Influence Over Infiltration In Order Sustainable Drainage Channels Planning. IPASJ International Journal of Information Technology (IIJIT) 2 (12): 1-6.

[29] Tsuchiya, K., Hara, Y., \& Thaitakoo, D. 2015. Linking food and land systems for sustainable peri-urban agriculture in Bangkok Metropolitan Region. Landscape and Urban Planning 143: 192-204.

[30] Rezai, Shamsudin, dan Mohamed. 2015. Urban Agriculture: A Way Forward to Food and Nutrition Security in Malaysia. Procedia - Social and Behavioral Sciences 216: $39-45$. 
[31] Bradley, K., \& Galt, R. E. 2013. Practicing food justice at Dig Deep Farms \& Produce, East Bay Area, California: self-determination as a guiding value and intersections with foodie logics. Local Environment: $1-15$.

[32] Kobayashi R, Yamada A, Hirooka H, Tabata Y, Zhang J, Nonaka K, Kamo M, Hayasaka K, Aoki Y, Kawamoto H, Shimonasako H. Changes in the cycling of nitrogen, phosphorus, and potassium in a dairy farming system. Nutrient cycling in agroecosystems. 2010 Jun 1;87(2):295-306.

[33] Kerton, S., \& Sinclair, A. J. (2009). Buying local organic food: a pathway to transformative learning. Agriculture and Human Values 27(4): 401-413.

[34] Goode, L. 2015. Urban Farming. Journal of Agricultural \& Food Information 16:189-195.

[35] Shanmugapriya. 2015. An overview of Eco friendly products Recycling. International Journal of Advanced Research 3 (7): 77-80.

[36] Benton, R. 2014. Reduce, Reuse, Recycle and Refuse. Journal of Macromarketing : 1-12.

[37] Porath, Sigal Ben. 2007. Civic Virtue out of Necessity Patriotism and Democratic Education. Theory and Research in Education 5 (1): 41-59.

[38] Machida, Satoshi. 2016. National Sentiments and Citizens' Attitudes in Japan Toward The Use of Force Against China. Asian Journal of Comparative Politics :1-17.
[39] Ambaras. 2007. Juvenile Delinquency and the National Defense State: Policing Young Workers in Wartime Japan, 1937-1945. The Journal of Asian Studies 63 (1): 31-60.

[40] Keling et al. 2009. The Impact of Singapore's Military Development on Malaysia's Security. Jurnal of Politics and Law 2 (2): 68-79.

[41] Budimansyah. 2016. Fundamental Sociological Symptoms as a Source of Occurrence of Turbulence in Indonesian Society During The PostReform. 1st UPI International Conference on Sociology Education.

[42] Lakshamanan. 2011. Gotong Royong. Hearts of Resilience: Singapore's Community Engagement Programme : 62 - 64. ISEAS-Yusof Ishak Institute.

[43] Chowdury et al. 2014. Developing 3Rs (Reduce, Reuse, and Recycle) Strategi for Waste Management in the Urban Areas of Bangladesh: Sosioeconomic and Climate Adoption Mitigation Option. Journal of Environmental Science, Toxiology and Food Technology 8 (5): 9-18.

[44] Prasetiyo, Wibowo Heru dkk. 2016. Urban Farming as A Civic Virtue Development in The Environmental Field. International Journal Of Environmental \& Science Education 11 (10): 3139-3146.

[45] Ditjenpothan Kementerian Pertahanan. 2014. Tatanan Dasar Bela Negara. Jakarta: Kemhan RI. 